\title{
HARMFUL MICROALGAE ASSEMBLAGE IN THE AQUACULTURE AREA OF AMAN ISLAND, NORTHEN STRAIT OF MALACCA
}

\author{
Roziawati Mohd Razali, ${ }^{1,2}$,Chui Pin Leaw ${ }^{3}$, Hong Chang Lim³, Lee Nyanti², Ismail \\ Ishak ${ }^{1}$, Po Teen Lim,"*
}

\author{
${ }^{1}$ Fisheries Research Institute Batu Maung, Department of Fisheries Malaysia,11960 Batu Maung, Pulau \\ Pinang, Malaysia \\ ${ }^{2}$ Faculty of Resource Science and Technology, Universiti Malaysia Sarawak, 94300 Kota Samarahan, \\ Sarawak, Malaysia. \\ ${ }^{3}$ Bachok Marine Research Station, Institute of Ocean and Earth Sciences, University of Malaya, Bachok, \\ 16310 Kelantan, Malaysia \\ *Corresponding author: ptlim@um.edu.my, poteenlim@gmail.com
}

\begin{abstract}
A field survey was carried out in Aman Island, the northern Strait of Malacca, to investigate the occurrence of harmful microalgae. The area is known for marine finfish cage-culture and blood cockle farming. Plankton samples were collected fortnightly between July 2011 and September 2013. A total of 58 phytoplankton genera were recorded; 37 belong to the diatoms, and 21 genera were dinoflagellates. Harmful microalgae species were identified microscopically, of which nine are bloom-forming species that responsible for fish kills. These included Akashiwo sanguinea, Chaetoceros affinis, Cha. curvisetus, Cha. laevis, Ceratium furca, C. fusus, Cochlodinium sp., Karlodinium australe and Noctiluca scintillans. Three Alexandrium species were identified from the samples, i.e. A. leei, A. affine and Alexandrium sp. Pulau Aman; some species in the genus have been known to associate with Paralytic Shellfish Poisoning (PSP). Diarrhetic Shellfish Poisoning (DSP)-toxin producers were also encountered in the water samples, viz. Dinophysis acuminata, D. caudata, Dinophysis sp. and Prorocentrum micans. The harmful diatom, Pseudo-nitzschia spp. that associated with Amnesic Shellfish Poisoning (ASP), was commonly found in the water samples. Cell abundance of each harmful microalga was enumerated. The results showed that cell densities of harmful microalgae were relatively low throughout the sampling period. The microalgae community was dominated by Ceratium furca in May 2012, with cell densities exceeding 70,000 cells L-1; no fish kill event was reported during the time. Even though no fish kill or shellfish poisoning was reported in the area, he presence of harmful microalgae albeit at low cell densities, may pose a potential threat to human health and seafood biosecurity. Therefore, regular phytoplankton monitoring is necessary to safeguard human health and seafood industries in the country.
\end{abstract}

\begin{abstract}
ABSTRAK Satu kajian telah dijalankan untuk menyiasat kewujudan mikroalga berbahaya di Pulau Aman, utara Selat Melaka. Kawasan ini telah dikenali dengan ternakan ikan marin dalam sangkar dan kerang. Sampel plankton telah diambil setiap dua minggu antara Julai 2011 sehingga September 2013. Sebanyak 58 taksa fitoplankton direkodkan; 37 adalah diatoms dan 21 genera adalah dinoflagelat. Spesis mikroalga berbahaya telah dikenal pasti secara mikroskopik, di mana sembilan dikenali sebagai spesies pembentuk ledakan yang boleh menyebabkan kematian ikan. Ini termasuklah Akashiwo sanguinea, Chaetoceros affinis, Cha. curvisetus, Cha. laevis, Ceratium furca, C. fusus, Cochlodinium sp., Karlodinium australe dan Noctiluca scintillans. Tiga spesies Alexandrium telah dikenal pasti dari sampel, iaitu A. leei, A. affine dan Alexandrium sp. Pulau Aman; beberapa spesies dalam genus ini dikaitkan dengan Keracunan Kerang-kerangan melumpuhkan (PSP). Penghasil toksin penybab Keracunan Kerang-kerangan cirit-birit (DSP) juga ditemui dalam sampel air, iaitu. Dinophysis acuminata, D. caudata, Dinophysis sp. dan Prorocentrum micans. Diatom berbahaya Pseudo-nitzschia spp. yang dikaitkan dengan Keracunan Kerang-kerangan amnesia (ASP) juga seringkali ditemui di dalam sampel air. Jumlah kepadatan sel mikroalga berbahaya telah dihitung. Hasil kajian menunjukkan bahawa kepadatan sel mikroalga berbahaya secara relatif adalah rendah sepanjang tempoh pensampelan. Pada Mei 2012, komposis mikroalga didominasi oleh C. furca dengan kepadatan sel melebihi 70,000 sel L-1 tetapi tiada kematian ikan dilaporkan pada masa itu. Walaupun tiada kejadian kematian ikan atau keracunan kerang-kerangan dilaporkan di kawasan itu, kehadiran mikroalga berbahaya walaupun dalam kepadatan sel yang rendah boleh menimbulkan ancaman kepada kesihatan manusia dan biosekuriti makanan laut. Oleh itu, pemantauan fitoplankton secara berkala adalah perlu untuk menjamin kesihatan manusia dan makanan laut di negara ini.
\end{abstract}

(Keywords: Aman Island; blood cockle; fish-cage; Harmful Algal Bloom; Malaysia; Strait of Malacca)

\section{INTRODUCTION}

Aman Island, an island in the northern part of the Straits of Malacca, is a very important marine finfish (grouper, snapper and sea bass) aquaculture area and blood cockle farming. In 2012, it produced
$1.8 \times 10^{3}$ tonnes of marine fish valued RM 18.26 million (Department of Fisheries Malaysia). To date, there has been very limited baseline data on the occurrence of harmful algal bloom (HAB) in the waters surrounding Aman Island. Red discoloration of the coastal waters caused by the dinoflagellate, 
Ceratium furca (Ehrenberg) Claparède et Lachmann was reported in 2007 [1]. However, their effect on fisheries was not investigated. The presence of several PSP toxin producers, Alexandrium species in the waters has also been reported [2]. Yet, the abundance and distribution of these species and other potential harmful algae are still under-studied.

About 300 phytoplankton species are considered harmful, and causes negative impacts to the economy, environment and public health [3]. Harmful microalgae are normally found in low cell numbers. However, under favorable environmental conditions, it may form extensive blooms that are capable to cause devastating effects on the environments and humans [4].

Microalgal species that are considered harmful are divided into two main groups: the toxin producers, which are capable to produce biotoxins that contaminating seafood or killing fishes; and the high-biomass plankton, which cause anoxia in the surrounding waters and subsequently cause mortalities of marine life. Several HAB species have the characteristics of both groups. Blooms of harmful algae posed high impacts on fishery industries by causing mass mortality in culture fishes, especially in fish cages due to oxygen depletion or fish gill damage [5]. HABs are also accompanied by shellfish toxicity events due to bioaccumulation of the biotoxin in the filter-feeding bivalves. Toxins may eventually transfer to humans by consumption of the intoxicated bivalves.

In Malaysia, the first report of HAB and shellfish toxicity was reported in 1976 when the marine dinoflagellate, Pyrodinium bahamense var. compressum (Böhm) Steidinger, Tester et Taylor bloomed in the Brunei Bay, Sabah, that poisoned 202 people, with seven casualties [6]. This species produce PSP toxins. This phenomenon continued to occur almost annually in the state [7]. On the other hand, PSP in Peninsular Malaysia was caused by another dinoflagellate species, i.e. Alexandrium tamiyavanichii Balech, and first reported in Sebatu, Malacca, where three people were hopitalized after eating the contaminated green mussels [8]. The latest case of PSP was recorded in November 2013 at Tanjung Gelang, Kuantan, Pahang, where eight port workers suffered illness after ingesting oyster contaminated with PSP toxins [9]. This recorded, for the first time, the occurrence of $P$. bahamense in the waters of east coast of Peninsular.

Massive blooms of microalgae are commonly attributed to fish kills in the natural waters or fish farming areas due to either hypoxia or anoxia in the surrounding environments or excretion of toxic bioactive compounds. Massive fish kills were reported in Penang in 2005 with losses estimated to not less than RM20 million, and the causative organism remained a mystery [reviewed in 10]. The latest reported case of massive fish kill occurred in Tanjung Kupang, Johor Straits in February 2014, where at least 10 fish farms and 250 traditional fishermen suffered losses due to mass mortality of fish caused by Karlodinium australe De Salas, Bolch et Hallegraeff $[11,12]$. The event recurred a year later, in February-March 2015 (Today, 2015).

The occurrence of harmful microalgal species in aquaculture areas poses potential threats to seafood safety, economic and environmental losses. Aman Island is one of the important areas for aquaculture activities in Penang, thus the baseline data on the occurrence and distribution of harmful algae in the area is essential in providing a proper management plan to minimize possible losses in the presence of $\mathrm{HAB}$ events and to provide early warning to the public and mariculturists. This study aims to determine the occurrence and abundance of harmful microalgae in the waters of Aman Island, and to investigate the association between species abundance and the environmental variables.

\section{MATERIALS AND METHODS}

\section{Sample collection, cell enumeration and species identification}

Field samplings were undertaken at five stations of Aman Island, the stations were selected surrounding the island (Figure 1); Station 1 (St. $1,05^{\circ} 15.941^{\prime} \mathrm{N}$, $100^{\circ} 24.329^{\prime} \mathrm{E}$ ) and 2 (St. 2, $05^{\circ} 15.500^{\prime} \mathrm{N}, 100^{\circ}$ $\left.24.041^{\prime} \mathrm{E}\right)$ were situated in a blood cockle farm; Station 3 (St. 3, $05^{\circ} 16.677^{\prime} \mathrm{N}, 100^{\circ} 23.970^{\prime} \mathrm{E}$ ) and 4 (St. $\left.4,05^{\circ} 17.095^{\prime} \mathrm{N}, 100^{\circ} 23.780^{\prime} \mathrm{E}\right)$ situated in the fish-cage culture area; while Station 5 (St. 5, $\left.05^{\circ} 17.223^{\prime} \mathrm{N}, 100^{\circ} 24.053^{\prime} \mathrm{E}\right)$ was located in the river mouth, outside the aquaculture area.

Phytoplankton samples were collected fortnightly during high tide from July 2011 to September 2013. Triplicates of 1-L water samples were collected at 2 $m$ depth using a Van Dorn water sampler. Samples 
were filtered through a $20 \mu \mathrm{m}$-mesh nylon sieve, and materials retained on the sieve were back-washed into a sample vial. Cells were preserved in Lugol's iodine solution. For cell enumeration, triplicate subsamples were taken for cell counts. One milliliter of concentrated phytoplankton samples was placed in a Sedgewick-Rafter counting chamber, observed and enumerated under an Olympus IX51 inverted research microscope (Olympus, Tokyo, Japan) at $100 \times$ magnification. Cell densities, in the unit of cells $\mathrm{L}^{-1}$, were measured from triplicate counts and presented as mean ( \pm standard deviation).
Identification of diatoms and dinoflagellates to genus level was based on the general morphological description of phytoplankton as in literature $[4,13$ 15]. Micrographs of each diatom and dinoflagellate species were captured with an attached cooled CCD camera and the digital images were analysed by Analysis ${ }^{\circledR}$ software (Soft Imaging System Inc., USA). For epi-fluorescence microscopy, fixed samples were stained with $1 \%$ calcofluor white (Fluka, Japan) and viewed under ultra-violet with a UV filter set as described in [16].

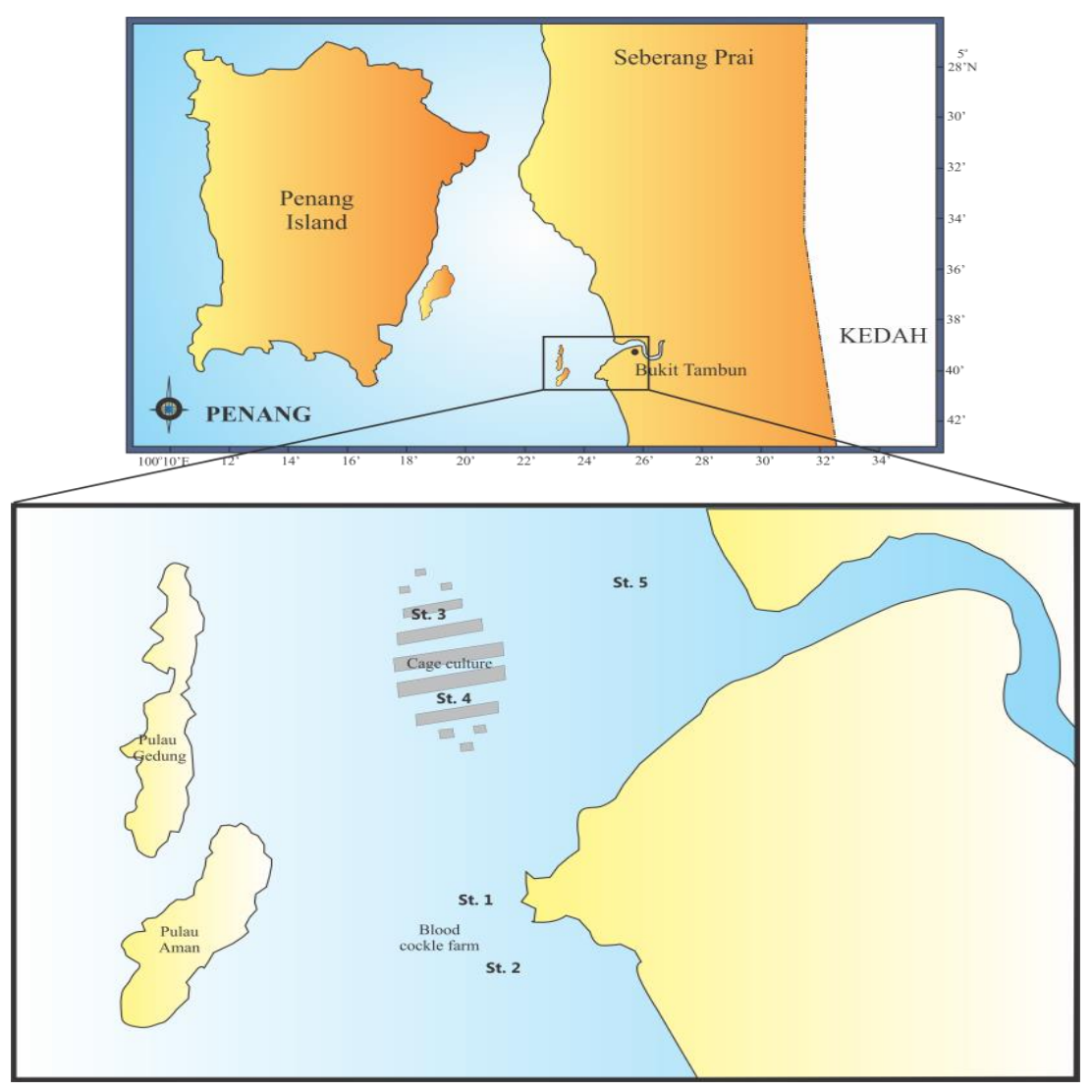

Figure 1. Map of Aman Island, Penang showing the five sampling sites.

\section{Physico-chemical parameters of seawater}

Physico-chemical properties of seawater including seawater temperature, salinity, $\mathrm{pH}$ and dissolved oxygen (DO) were analyzed in situ using a YSI YS16920 multi-parameter water quality probe (Yellow Springs, Ohio, USA). Water samples were brought back to the laboratory and immediately analyzed spectro-photometrically for dissolved inorganic nutrients $\left(\mathrm{N}-\mathrm{NO}_{3}, \mathrm{~N}-\mathrm{NO}_{2}, \mathrm{~N}-\mathrm{NH}_{3}\right.$, $\mathrm{P}-\mathrm{PO}_{4}, \mathrm{Si}-\mathrm{SiO}_{2}$ ) by using a HACH DREL 2010 (HACH, USA) according to manufacturer's instructions. Concentrations of chlorophyll $a$ (Chl a) were measured in situ using a Hyrolab MS5 chlorophyll probe (Loveland, CO, USA).

\section{Data Analysis}

Principle component analysis (PCA) was applied to examine the pattern and distribution of potentially harmful microalgae composition. PCA was run with PC-ORD program [17], with 1000 permutations to test for the significance of axes. 


\section{RESULTS AND DISCUSSION}

A total of 58 taxa of phytoplankton were documented in this study. Diatom, Chaetoceros sp., Skeletonema sp. and Thalassiosira sp. are found mostly abundant in the sampling sites. Station 4 showed the highest indices of Shannon $(H)$ and species evenness $(E)$, with 2.18 and 0.297 , respectively (Table 1 ). Species of dinoflagellates and diatoms detected in Aman Island, Penang are listed in Table 2 and Table 3, respectively.
The harmful algae found in the sampling sites are listed in Table 4 . The toxin producers are mainly dominated by Alexandrium spp., Dinophysis spp., Prorocentrum spp. and Pseudo-nitzschia spp. (Figure 2), while the high-biomass plankton are Akashiwo sanguinea, Karlodinium australe, Cochlodinium sp, Ceratium spp., Noctiluca scintillans and Chaetoceros spp. (Figure 3). Cell densities of the harmful microalgae at five sampling stations in Aman Island, Penang are shown in Figure 4.

Table 1. Diversity indices of phytoplankton based on Shannon-wiener Index $(H)$ and evenness $\left(\mathrm{e}^{\wedge} H / S\right)$ at each station of Aman Island, Penang, Malaysia

\begin{tabular}{llllll}
\hline & St. 1 & St. 2 & St. 3 & St. 4 & \multicolumn{1}{c}{ St. 5 } \\
\hline Taxa (S) & 31 & 34 & 36 & 36 & 33 \\
Shannon Weiner (H) & 1.961 & 1.949 & 2.016 & 2.183 & 1.919 \\
Evenness (E) & 0.285 & 0.265 & 0.268 & 0.297 & 0.264 \\
\hline
\end{tabular}

Table 2. Dinoflagellate taxa of Aman Island, Penang identified in this study. Asterisk indicates harmful taxon.

\begin{tabular}{|c|c|}
\hline \multicolumn{2}{|c|}{ Dinoflagellates } \\
\hline Alexandrium spp. * & Karlodinium australe * \\
\hline Akashiwo sanguinea & Peridinium spp. \\
\hline Ceratium spp. * & Prorocentrum spp. \\
\hline *Dinophysis spp. * & Protoperidinium spp. \\
\hline Fragilidinium sp. & Pyrophacus sp. \\
\hline Gonyaulax sp. & Polykrikos sp. \\
\hline Gyrodinium spp. & Scripsiella sp. \\
\hline Gymnodinium spp. * & \\
\hline
\end{tabular}

Table 3. Diatom taxa of Aman Island, Penang identified in this study. Asterisk indicates harmful taxon.

\begin{tabular}{|c|c|c|}
\hline Pennate Diatom & \multicolumn{2}{|c|}{ Centric Diatom } \\
\hline Amphora spp. & Asteromphalus spp. & Leptocylindrus spp. \\
\hline Asterionella spp. & Bacteriastrum spp. & Lithodesmium spp. \\
\hline Bacillaria paxillifera & Bellerochea spp. & Melosira spp. \\
\hline Cylindrotheca closterium & Chaetoceros spp. * & Meuniera membranacea \\
\hline Gyrosigma spp. & Corethron spp. & Noctiluca scintillans \\
\hline Navicula spp. & Coscinodiscus spp. & Odontella \\
\hline Nitzschia longissima & Detonula spp. & Paralia \\
\hline Pleurosigma spp. & Ditylum spp. & Planktoniella sol \\
\hline Pseudo-nitzschia spp. ${ }^{*}$ & Eucampia spp. & Rhizosolenia spp. \\
\hline Surirella spp. & Guinardia spp. & Skeletonema spp. \\
\hline Synedra spp. & Hemiaulus spp. & Thalassiosira spp. \\
\hline Strephanophyxis spp. & Helicotheca tamensis & Triceratium spp. \\
\hline Thallasionema spp. & Lauderia spp. & \\
\hline
\end{tabular}


Table 4. Harmful microalgae identified from Aman Island, Penang (July 2011-September 2013), with the frequency of occurrence throughout the 285 samplings, the maximum cell densities (cells $\mathrm{L}^{-1}$ ), and the month and stations where the maximum cell densities were observed.

\begin{tabular}{|c|c|c|c|c|}
\hline Species & Frequency & $\begin{array}{l}\text { Maximum cell } \\
\text { density (cells L-1) }\end{array}$ & $\begin{array}{l}\text { Month/station } \\
\text { of maximum } \\
\text { abun-dance }\end{array}$ & Potential Impact \\
\hline \multicolumn{5}{|c|}{ Potentially toxic species } \\
\hline Alexandrium spp. & 47 & 2400 & Sep. 2013/ St.2 & PSP \\
\hline Dinophysis caudata & 58 & 3600 & Nov. 2012/ St.3 & DSP \\
\hline Karlodinium spp. & 14 & 2,000 & Jan. 2012/ St.3 & $\begin{array}{l}\text { Ichtyotoxicity, } \\
\text { fish kill }\end{array}$ \\
\hline Pseudo-nitzchia spp. & 56 & 66,000 & Aug. 2013/ St.5 & ASP \\
\hline \multicolumn{5}{|l|}{ Bloom forming species } \\
\hline Akashiwo sanguinea & 40 & 800 & Nov. 2012/ St. 3 & Red tides \\
\hline Chaetoceros spp. & 58 & 784,300 & Sept. 2014/ St. 2 & $\begin{array}{l}\text { Red tides, } \\
\text { fish kill }\end{array}$ \\
\hline Ceratium furca & 56 & 76,500 & May 2012/ St. 3 & $\begin{array}{l}\text { Red tides, } \\
\text { fish kill }\end{array}$ \\
\hline Ceratium fusus & 54 & 900 & Feb. 2014/ St. 2 & $\begin{array}{l}\text { Red tides, } \\
\text { fish kill }\end{array}$ \\
\hline $\begin{array}{l}\text { Prorocentrum } \\
\text { micans }\end{array}$ & 53 & 2100 & Sep. 2013/ St. 2 & Red tides \\
\hline Noctilluca scintillans & 43 & 1300 & July 2012/ St. 2 & Fish kill \\
\hline
\end{tabular}

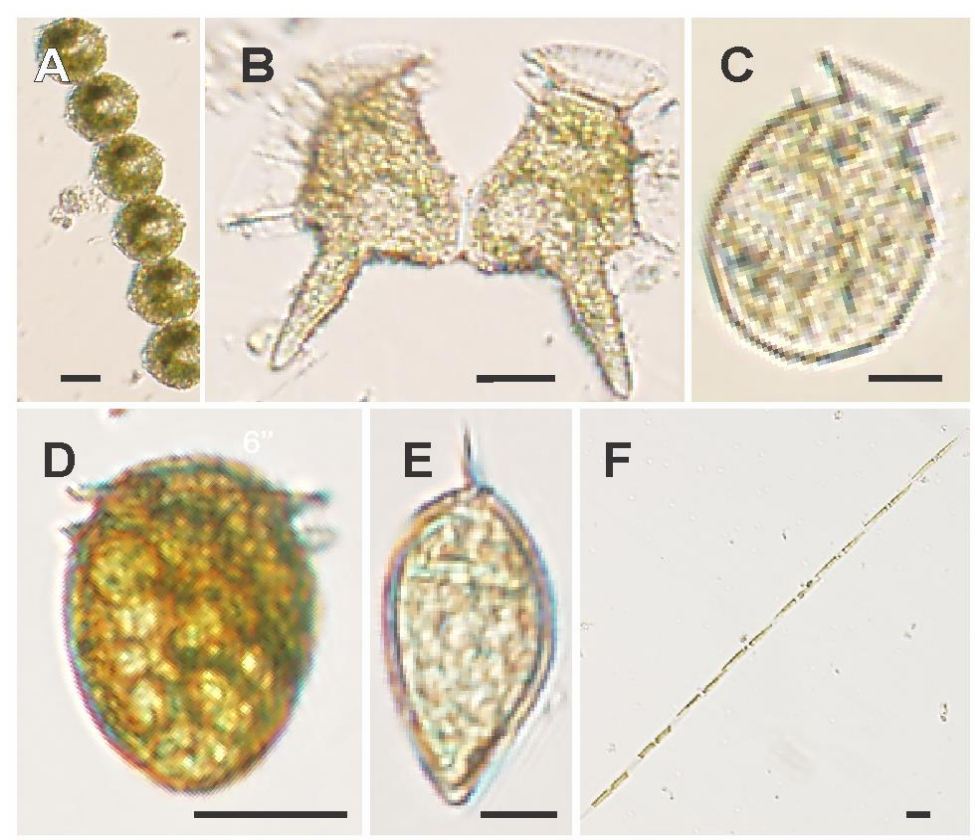

Figure 2. Potentially toxins-producing microalgae found in Aman Island, Penang. A, Alexandrium sp.; B, Dinophysis caudata; C, D. acuminata; D, Dinophysis sp. 1; E, Prorocentrum micans ; F, Pseudo-nitszchia sp. 

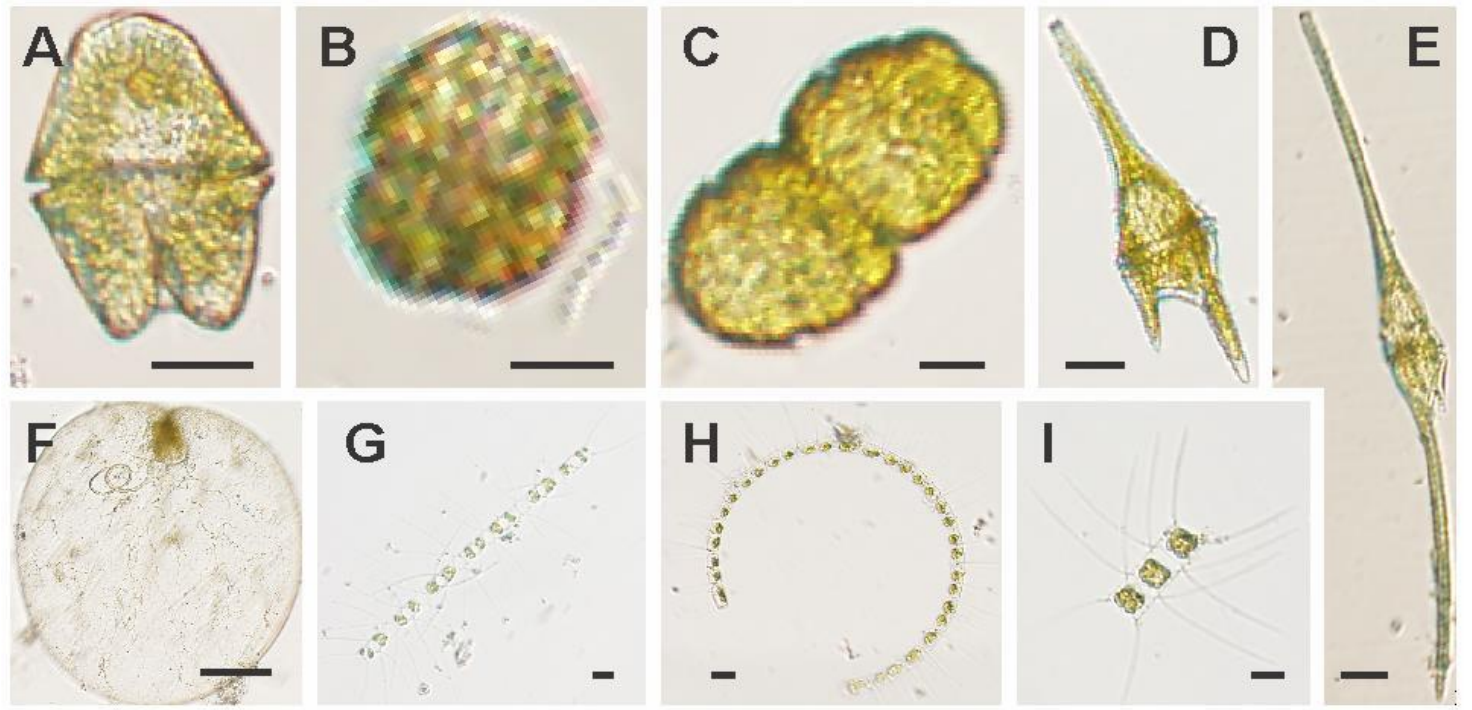

Figure 3. Potentially fish-killing microalgae found in Aman Island, Penang. A, Akashiwo sanguinea; B, Karlodinium australe; C, Cochlodinium sp; D, Ceratium furca; E, Ceratium fusus; F, Noctiluca scintillans; G, Chaetoceros affinis; H, C. curvisetus; I, C. laevis.

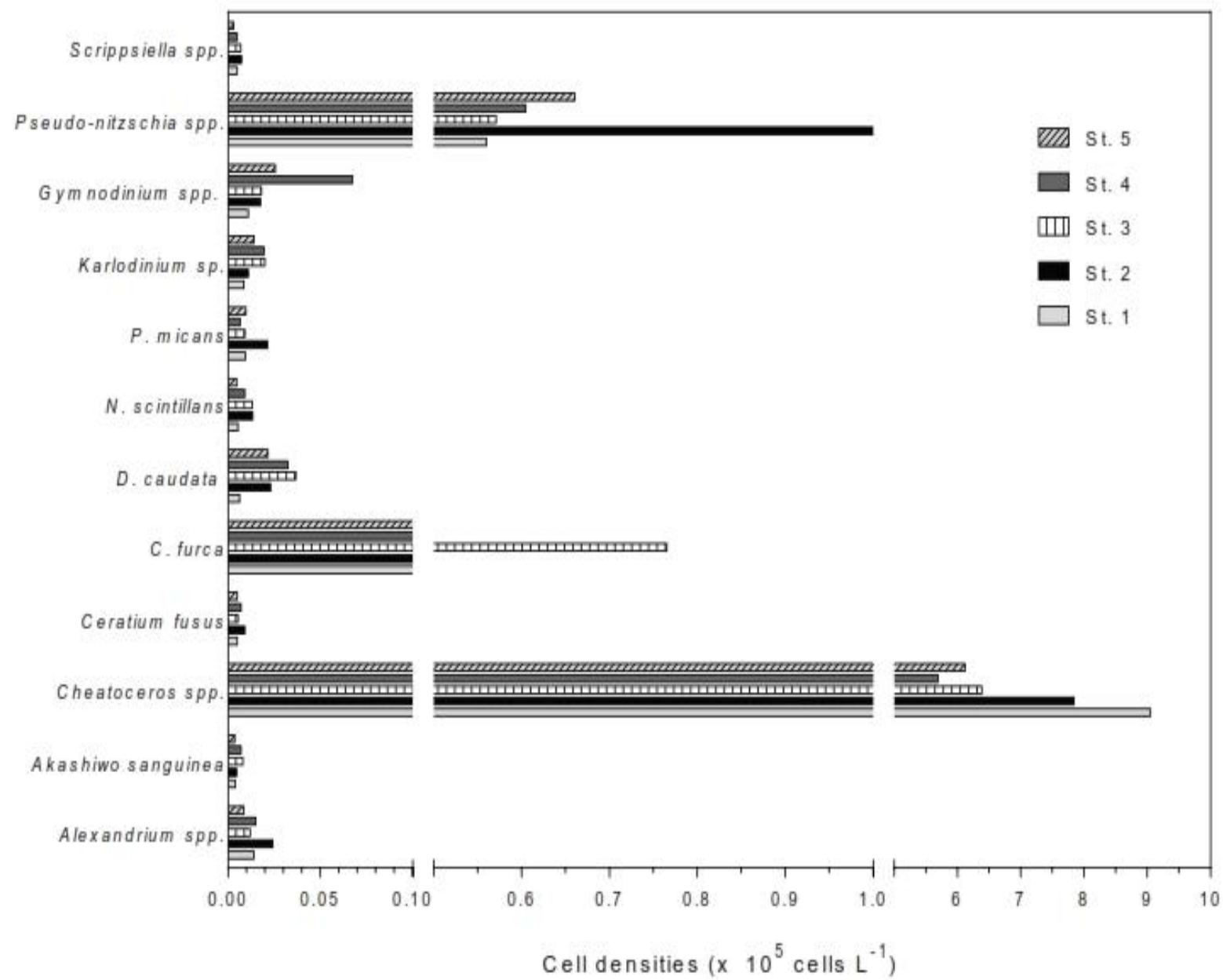

Figure 4. Cell densities of potentially harmful microalgae found in Aman Island, Penang. 


\section{Potentially toxic species}

Three species of Alexandrium, namely A. leei Balech (Figure 5), A. affine (Inoue et Fukuyo) Balech (Figure 6) and Alexandrium sp. Pulau Aman were found at all sampling stations, at densities ranging from 40 to 2430 cells $\mathrm{L}^{-1}$ and the highest density was recorded from Station 2 in the cockle culture area, on September 2013. Several species in this genus have been indicated to produce saxitoxins (STXs), which lead to Paralytic Shellfish Poisoning (PSP) in humans [18]. In several countries, the presence of the PSP-toxin producing species in the concentrations of 20-100 cells $\mathrm{L}^{-1}$ has triggered further toxin analysis in shellfish, and sometimes cell density as low as 20 cells $\mathrm{L}^{-1}$ could cause the closure and ban of shellfish harvesting [19]. At present, PSP is the only HAB-related shellfish poisoning that has been documented in Malaysia. Three people were poisoned in Sebatu, Malacca in 1991 while one death and six persons were hospitalized in Tumpat, Kelantan due to consuming shellfish contaminated with toxic Alexandrium species, A. minutum Halim and A. tamiyavanichii $[10,15,20]$.
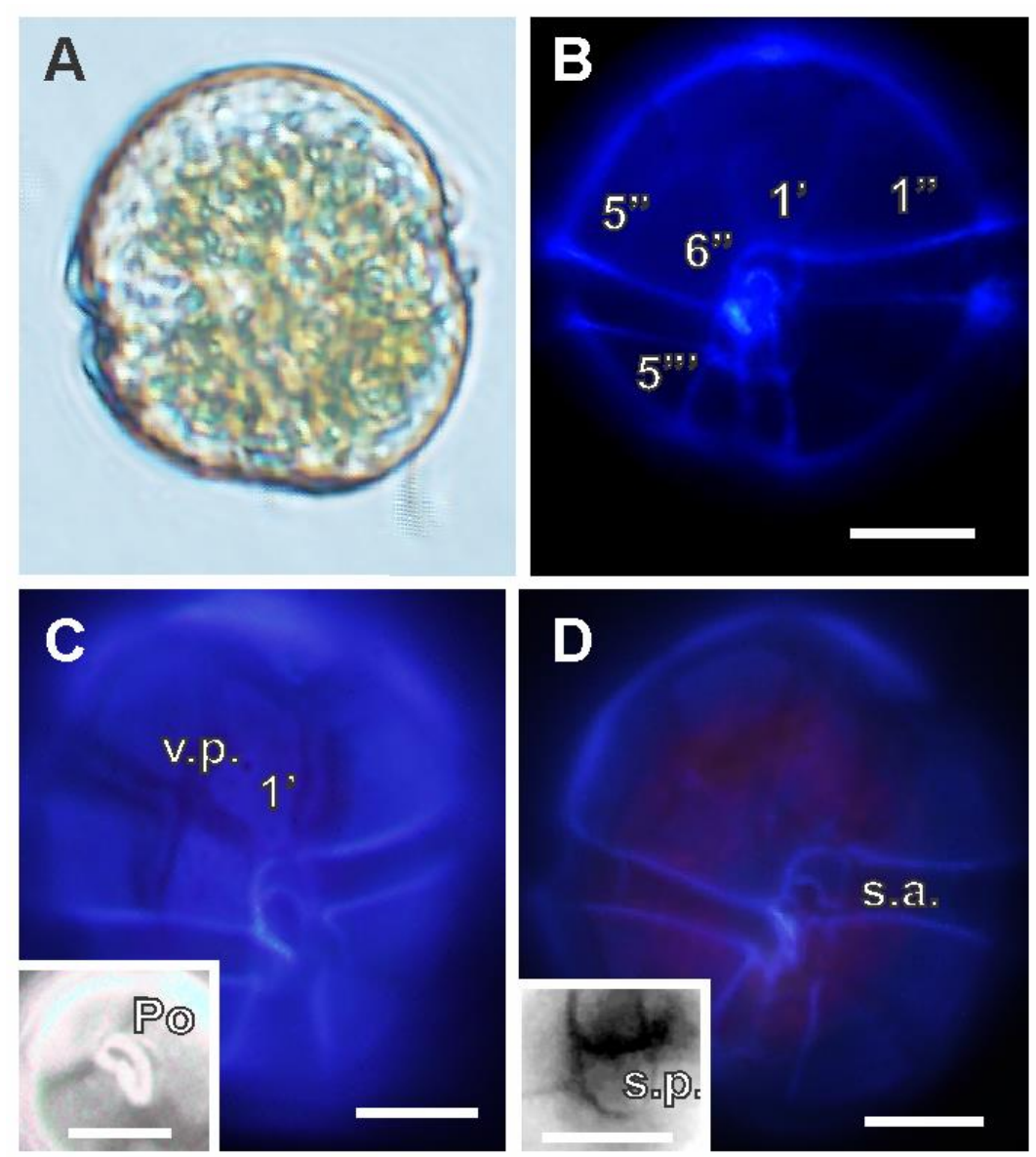

Figure 5. Alexandrium leei from Aman Island. (A) a roundish vegetative cell with conical epitheca; (B) ventral view of a cell showing the first apical plate $\left(1^{\prime}\right)$, first precingular $\left(1^{\prime \prime}\right)$, sixth precingular plate $\left(6^{\prime \prime}\right)$ (C); ventral pore (v.p) is in the middle of 1'and apical view showing apical pore plate (Po); (D) wide anterior sulcal plate (s.a.) and antapical view showing the wide posterior sulcal plate (s.p). Scale bars $=10 \mu \mathrm{m}$. 


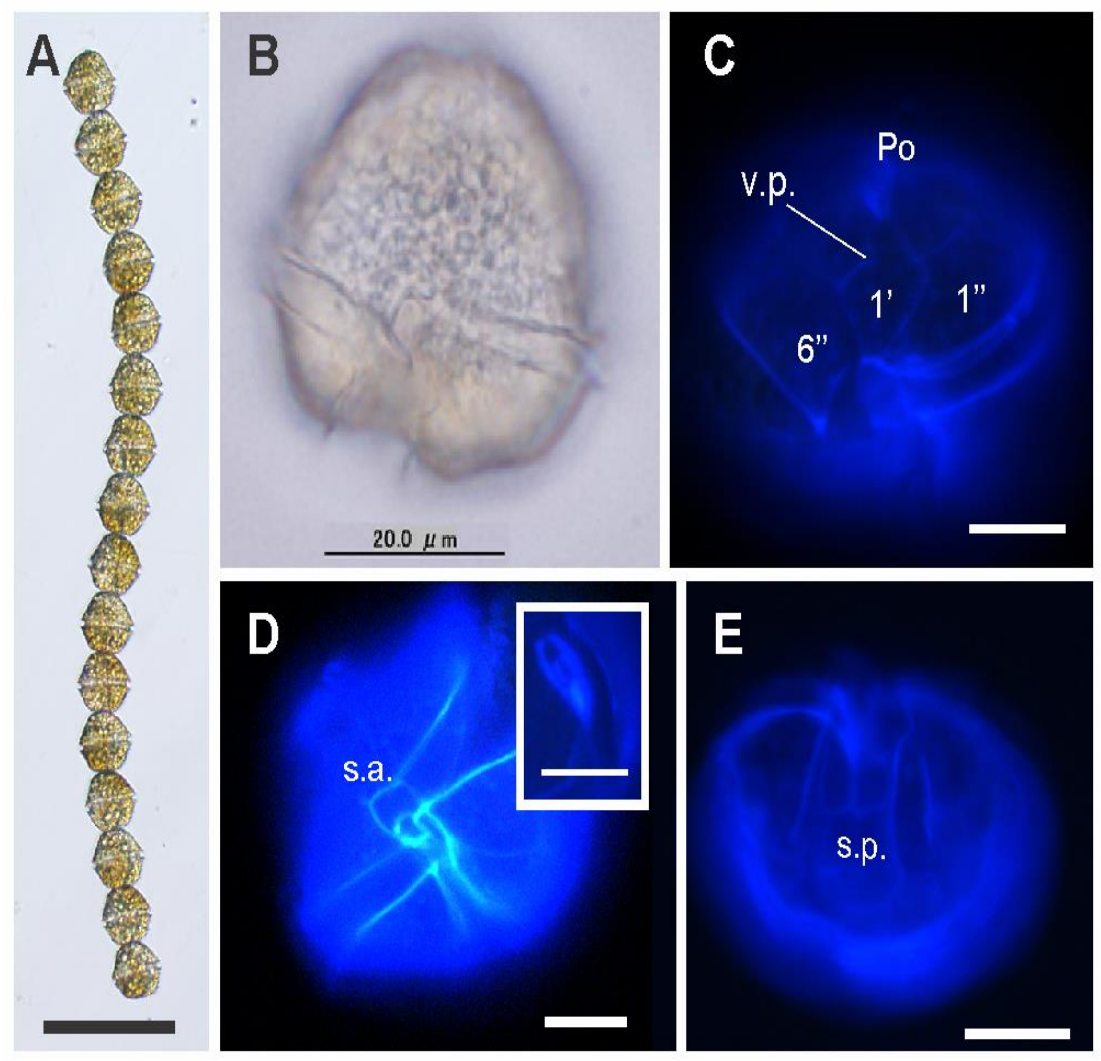

Figure 6. Alexandrium affine from Aman Island. (A) chain with 16 vegetative cells (B) single cell showing position of nucleus; (C) ventro-apical view showing the first apical plate $\left(1^{\prime}\right)$, first precingular $\left(1^{\prime \prime}\right)$, sixth precingular plate (6"), location of the ventral pore (v.p) (D) ventral view showing the plate pattern of sulcul (s.a) and Po plate; (E) antapical view showing the elongated posterior sulcul (s.p.). Scale bars $=10 \mu \mathrm{m}$.

Three Dinophysis species, the causative organisms of DSP were found in the study area. Dinophysis caudata Saville-Kent (Figure 2B) and D. acuminata Claparède et Lachmann (Figure 2C) were observed at all sampling stations, with the cell densities ranged from 60-3660 cells $\mathrm{L}^{-1}$ and 100-200 cells $\mathrm{L}^{-1}$, respectively (Figure4). Meanwhile, Dinophysis sp. 1 (Figure 2D) was rarely found throughout the sampling period. The highest cell density of D. caudata was recorded at Station 3. Holmes et al. [21] reported that the low concentration of $D$. caudata may cause persistent low concentrations of DSP toxins in mussels in the Singapore waters. In Netherlands several cases of gastrointestinal disorders have been recorded due to consumption of raw or cooked mussels, Mytilus edulis Linnaeus, that contaminated by D. acuminata [22]. In Malaysia, no incidence of DSP has yet been reported. Symptoms of DSP are very similar to diarrhea caused by bacterial poisoning and may contribute to the underreporting and under-diagnostics of DSP cases.
Prorocentrum micans Ehrenberg (Figure 2E) was present in all sampling stations, but at low densities, ranging from $40-2100$ cells $\mathrm{L}^{-1}$. DSP caused by P. micans was reported from the Galician Rías Altas, Spain, in 1978 and 1979 [reviewed in 23]. In Philippines, bloom of this species had caused tones of milkfish mortality at the affected area [24]. Similar case was also reported in Turkey [25]. Prorocentrum micans has not yet been reported to cause bloom in the Malaysian waters. However, water discoloration was documented occur at the nearby finfish farms, in the Tebrau Strait in 2002 due to P. minimum, but no massive fish kill event was reported [26].

Of the 38 species of diatoms observed, only one species of toxic diatom Pseudo-nitzchia spp. (Figure 2F) was found at all sampling stations, ranging between 100 cells $\mathrm{L}^{-1}$ and $1.2 \times 10^{5}$ cells $\mathrm{L}^{-1}$. The highest cell density of this species was recorded at Station 2 nearby the cockle culture area. Almost one third of the species in this genus 
produce the neurotoxin domoic acid, the causative agent of amnesic shellfish poisoning (ASP) [27, 28]. Domoic acid poisoning was first reported in 1987, where several taken ill including three deaths due to consuming cultured mussels from Prince Edward Island, Canada contaminated with $P$. multiseries (Hasle) Hasle [29]. In the Alabama coastal waters of the northern Gulf of Mexico (NGOM), a toxic Pseudo-nitzschia sp. was reported blooms at density cell, $5.05 \times 10^{6}$ cells L ${ }^{-1}$ in June 2009 that resulted in the accumulation of domoic acid (DA) in fish [30]. In Malaysia, no incidence of ASP has yet been reported, however Pseudo-nitzschia spp. has been shown to be widely distributed in Malaysian waters $[31,32,33]$, and a toxic species, $P$. kodamae has been reported [27].

\section{Bloom forming species}

Akashiwo sanguinea (Hirasaka) Hansen et Moestrup (Figure 3A) form extensive blooms that discolored the wa ter red, and have been associated with shellfish and fish kills [34]. In this study $A$. sanguinea was found at all sampling stations, ranging from $50-800$ cells $\mathrm{L}^{-1}$.

Several naked dinoflagellates that can cause fish mortality, such as Karlodinium australe (Figure 3B) and Cochlodinium spp. (Figure 3C) was found at low densities at all sampling stations, with the highest cell densities at 2000-6700 cells $\mathrm{L}^{-1}$. The latest HABs and mass mortality of caged fish in Tanjung Kupang, Johor (2014-2015) was attributed to the species, $K$. australe [12]. The occurrence of K. micrum (Leadbeater et Dodge) Larsen [currently known as $K$. veneficum (Ballantine) Larsen] was also reported for the first time in aquaculture areas of the Tebrau Strait in 2009 [35]. Karlodinium veneficum blooms was reported in the hybrid striped bass aquaculture pond in Chesapeake Bay and caused fish kills [36]. The species was found to produce karlotoxin, an ichthyotoxin that is lethal to fish through damage of gill epithelia [37]. In 2005, Cochlodinium polykrikoides Margalef was reported responsible for the bloom in Sepanggar Bay, Sabah, where cell abundance reached a maximum value of $6 \times 10^{6}$ cells $\mathrm{L}^{-1}$ causing the death of fish in cages [38].

The genus Ceratium is another non-toxic bloom forming marine dinoflagellates that are commonly found in the east coast of Peninsular Malaysia, Malacca Strait and Tebrau Strait $[35,39,40]$. In this study, two species, Ceratium furca (Figure 3D) and C. fusus (Ehrenberg) Kingston (Figure 3E), were detected at all stations, with densities ranging between $30-76,500$ cells $\mathrm{L}^{-1}$ and $50-900$ cells $\mathrm{L}^{-1}$, respectively. Ceratium furca was observed at high density at Station 3 in the cage culture area, in May 2012. High abundance of these species could cause fish mortality due to clogging or damaging the fish gills [41]. The first red tide event caused by C. furca was reported in 2007 in Lumut, Perak [1]. Blooms of C. furca caused water discoloration at the northern of Malacca Strait; however no fish kill event was reported [40]. In Aman Island, there was no reported fish kill in the area during the period of the study.

Noctiluca scintillans (Macartney) Kofoid et Swezy (Figure 3F) is common in all sampling stations. This species was reported to cause water discoloration in Penang and the Tebrau Strait [42]. The species is common throughout the Southeast Asian waters as well as the Japanese coastal waters [43]. Although this species does not produce toxins, it accumulates ammonia in the vacuole, which may be toxic to fish [44]. Blooms of N. scintillans have been associated with massive fish and marine invertebrate kills in Dapeng Bay, the South China Sea [45].

The presence of marine diatoms Chaetoceros affinis Lauder (Figure 3G), C. curvisetus Cleve (Figure $3 \mathrm{H}$ ) and C. leavis Leuduger-Fortmorel (Figure 3I) may pose a threat to cage culture activities at the surrounding waters of Aman Island. Among other diatoms, Chaetoceros spp. occurred in the highest cell densities $\left(<7.0 \times 10^{6}\right.$ cells $\left.\mathrm{L}^{-1}\right)$. Similarly, study carried by [46] showed that Chaetoceros spp. dominated and occurred in high cell density $\left(<5000\right.$ cells L $\left.{ }^{-1}\right)$. Chaetoceros has been reported to be associated with fish kill events since 1961 [47]. Clogging of the spines of Chaetoceros irritated cultured marine fish, leading to mucus production and eventually fish death owing to suffocation.

\section{Relationship between harmful algae cell abundance and the environmental variables}

The analysis of principal component (PCA) was performed to investigate the relationship between cell densities of harmful microalgae and the environmental variables (Figure 7). The analysis was performed on the dataset fro $m$ five sampling stations of Aman Island for the period of 28 months. The environmental variables examined are salinity, 
seawater temperature, dissolved oxygen (DO), $\mathrm{pH}$, concentrations of phosphate, nitrate, nitrite and ammonia. The biplot results showed that salinity, $\mathrm{pH}$ and temperature were the most influential factors in regulating the cell density of Chaetoceros sp. and $A$. sanguinea, whereas other harmful algae were weakly influenced by the physical parameters.

Prorocentrum micans and $N$. scintillans were negatively related to thephysical parameters, and weakly related to chemical parameters. Based on the biplot, all stations indicated that chemical parameters were negatively related to the abundance of harmful microalgae. All plots close to the centre in the ordination diagram denoted that cell density of the harmful microalgae was poorly related to environmental factors and suggested that the abundances could be driven by other factors not considered in the analysis.

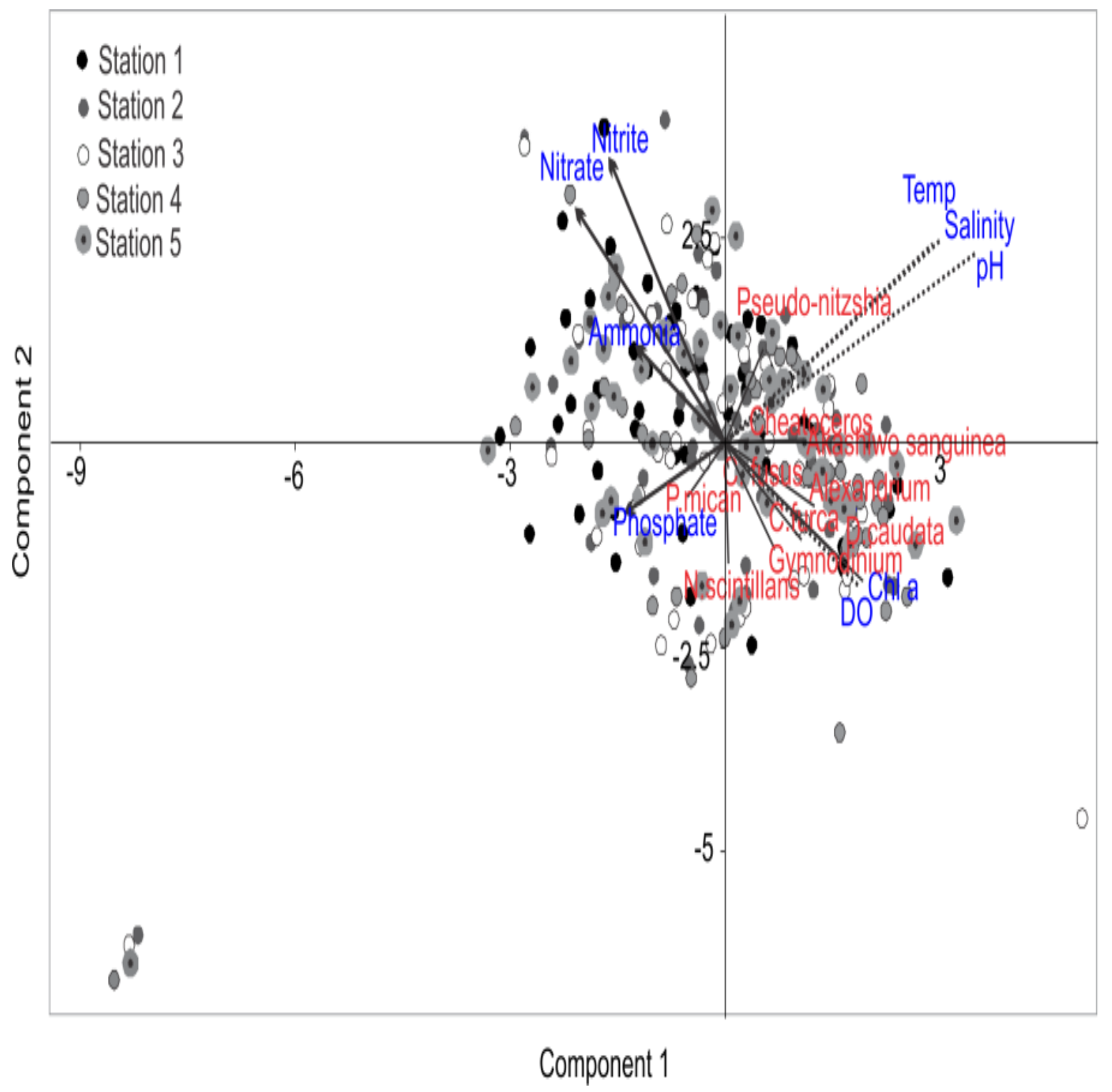

Figure 7. Principle Component Analysis (PCA) generated from nine environmental variables and cell densities of harmful micralgae from Aman Island 


\section{CONCLUSION}

Results from this study indicated that potentially toxic Alexandrium spp., D. caudata, Pseudonitzchia spp. are common in Aman Island, Penang especially in the blood cockle culture area. The presence of fish killing microalgae such as $A$. sanguinea, C. furca, C. fusus, N. scintillans, $K$. australe and Chaetoceros spp. especially in the cage culture area is alarming, even though no incidence of HABs was reported in the area during the period of this study. Factors contributing to the abundance and occurrence of the harmful microalgae in Aman Island still need further investigation as the current environmental variables examined revealed poor correlations. Presence of the harmful microalgae in the aquaculture area, even in low densities may pose potential threat; thus regular systematics plankton monitoring should be implement to safeguard the mariculture of Aman Island.

\section{ACKNOWLEDGEMENTS}

This work was funded by the Malaysian Government through the Ministry of Science, Technology and Innovation (MOSTI) ScienceFund [02-0306-SF0011, 04-01-03-SF1011]; the Ministry of Education JSPS-COMSEA matching fund [GA0022014] and HiCoE fund [IOES-2014C]; and University of Malaya UMRG [RU006A/B-2014]. This paper forms part of the MSc. thesis of Mohd Razali R., supported under JPA.

\section{REFERENCES}

1. Annual Report Fisheries Research Institute. (2007). Fisheries Research Institute, Department of Fisheries, Ministry of Agriculture Malaysia Publishing.

2. Usup G., Leaw C.P., Asmat A. and Lim P.T. (2002). Alexandrium (Dinopyhceae) species in Malaysian waters. Harmful Algae 1:265-275.

3. Hallegraeff G. M. (2003). Harmful algal blooms: a global overview. In: Manual on Harmful Marine Microalgae. Monographs on oceanic methodology 11. (eds. Hallegraeff, G. M. Anderson, D. M. and Cembella, A. D.) UNESCO Publishing, Paris, pp. 25-45.
4. Moestrup Ø. and Larsen J. (1992). Potentially toxic phytoplankton. 1. Haptophyceae (Prymnesiophyceae). ICES identification leaftets for plankton.

5. Rensel J.E. and Whyte J.N.C. (2003). Finfish mariculture and harmful algal blooms. In: Manual on Harmful Marine Microalgae. Monographs on oceanic methodology 11. (eds. Hallegraeff G.M., Anderson D.M. and Cembella, A.D.) UNESCO Publishing, Paris, pp. 693-722.

6. Roy R.N. (1997). Red tide and outbreak of paralytic shellfish poisoning in Sabah. Medical Journal of Malaysia 31:247-251.

7. Usup G., Ahmad A., Matsuoka K., Lim P.T. and Leaw C.P. (2012). Biology, ecology and bloom dynamics of the toxic marine dinoflagellate Pyrodinium bahamense. Harmful Algae 14: 301-312.

8. Usup G., Leaw C.P. and Asmat A. (2002). Increasing important of harmful algal blooms in Malaysia. In: Proceedings of the Regional Symposium on Environment and Natural Resources (eds. Omar R., Ali Rahman Z., Latiff M.I., Lihan I. and Adam J. H.) Kuala Lumpur. pp. 144-153.

9. Pahang Daily, August 2014.

10. Lim P.T., Usup G. and Leaw C.P. (2012). Harmful Algal Blooms in Malaysian waters. Sains Malaysiana 41(12): 15091515.

11. The Star News. 7 April, 2014.

12. Lim H.C., Leaw C.P., Tan T.H., Kon N.F., Yek L.H., Hii K.S., Teng S.T., Mohd Razali R., Usup G., Iwataki M. and Lim P.T. (2014). A bloom of Karlodinium australe (Gymnodiniales, Dinophyceae) associated with mass mortality of cagecultured fishes in West Johor Strait, Malaysia. Harmful Algae 40: 51-62.

13. Hasle G.R. and Syvertsen E.E. (1997). Marine Diatoms. In: Identifying Marine Phytoplankton. (ed. Tomas C.R.) Academic Press, San Diego, pp. 5-361.

14. Steidinger K.A. (1997). Dinoflagellates. In: Identifying Marine Phytoplankton. (ed. Tomas C. R.) Academic Press, San Diego, pp. 387-570. 
15. Omura T., Iwataki M., Borja V.M., Takayama H. and Fukuyo Y. (2012). Marine Phytoplankton of the Western Pacific. Kouesiha Kouseikaku Co. Ltd, Tokyo.

16. Lim P.T., Leaw C.P. and Ogata T. (2007). Morphological variation of two Alexandrium species responsible for paralytic shellfish poisoning in Southest Asia. Botanica Marina 50: 14-21.

17. McCune B. and Mefford M.J. (2006). PCORD. Multivariate analysis of ecological data. Version 5.10. MJM Software, Gleneden Beach, Oregon, USA, p. 300.

18. Backer L.C., Fleming L.E., Rowan A.D. and Baden D.G. (2003). Epidemology, public health and human disease associated with harmful marine algae. In: Manual on Marine Microalgae. Monographs on oceanic methodology 11. (eds. Hallegraeff G.M., Anderson D.M. and Cambella A.D.) UNESCO Publishing, Paris, pp. 723-749.

19. Anderson D.M., Andersen P., Bricelj V.M., Cullen J.J., and Rensel J.E. (2001). Monitoring and Management Strategies for Harmful Algal Blooms in Coastal Waters, APEC \#201-MR-01.1, Asia Pacific Economic Program, Singapore, and Intergovernmental Oceanographic Commission Technical Series No.59, Paris.

20. Lim P.T., Leaw C.P. and Usup G. (2004) First incidence of paralytic shellfish poisoning on the east coast of Peninsular Malaysia. In: Marine Science into the New Millennium: New Perspectives and Challenges. (eds. Phang S.M., Chong V.C., Ho, S.S., Mokhtar N., Ooi J.L.S.) University of Malaya Maritime Research Centre, Kuala Lumpur, Malaysia, pp. 661667.

21. Holmes M.J., Teo, S.L.M., Lee F.C. and Khoo H.W. (1991). Persistent low concentrations of diarrhetic shellfish toxins in green mussels Perna viridis from the Johor Strait, Singapore: first record of diarrhetic shellfish toxins from South-East Asia. Marine Ecology Progress Series 181: 257-268.

22. Kat M. (1984) Diarrhetic mussel poisoning in the Netherlands related to the dinoflagellate Dinophysis acuminata. Antonie van Leewenhoek 49: 417-427.

23. Reguera B., Riobo P., Rodriguez F., Diaz P.A., Pizarro G. and Paz B. (2014) Dinophysis toxins: causative organisms, distribution and fate in shellfish. Marine Drug 12: 394-461.

24. Azanza R.V., Fukuyo Y., Yap L.G. and Takayama H. (2005) Prorocentrum minimum blooms and its possible link to a massive fish kill in Bolinao, Pangasinan, Northern Philippines. Harmful Algae 4: 519-524.

25. Turkoglu M. and Koray T. (2004). Algal blooms in surface waters of the Sinop Bay in the Black Sea, Turkey. Pakistan Journal Biological Science 7: 1577-1585.

26. Usup G., Cheah M.Y., Roziwan, Ng B.K., Leaw C.P., Othman M. and Faazaz A.L. (2004). Identification of the species responsible for the harmful algal bloom event in Selat Tebrau in 2002. Malaysian Applied Biology 35: 59-62.

27. Teng S.T., Lim H.C., Lim, P.T., Dao V.H., Bates S.S. and Leaw C.P. 2014. Pseudo-nitzschia kodamae sp. nov. (Bacillariophyceae), a toxigenic species from the Strait of Malacca, Malaysia. Harmful Algae 34: 17-28.

28. Dao V.H., Phan V.B., Teng S.T., Uchida H., Leaw C.P., Lim P.T., Suzuki T. and Pham K.Y. 2015. Pseudo-nitzschia fukuyoi (Bacillariophyceae), a domoic acidproducing species from Nha Phu Bay, Khanh Hoa Province, Vietnam. Fisheries Science DOI 10.1007/s12562-015-0864-9

29. Lizzy M. (2001). Domoic acid: a fascinating marine toxin. Environmental toxicology and Pharmacology 9: 79-85.

30. Justin D.L., Alison R., Hugh L.M., William L.S. and Carol P.D. (2013). Characterization of a toxic Pseudonitzschia spp. bloom in the Northern Gulf of Mexico associated with domoic acid accumulation in fish. Harmful Algae 26: 20-32.

31. Lim, H.C., Leaw, C.P., Su, S.N.P., Teng, S.T., Usup, G., Mohammad-Noor, N., Lundholm, N., Kotaki, Y. \& Lim, P.T. (2012). Morphology and molecular 
characterization of Pseudo-nitzschia (Bacillariophyceae) from Malaysian Borneo, including the new species Pseudonitzschia circumpora sp. nov. Journal of Phycology 48(5): 1232-1247.

32. Lim, H. C., Lim, P. T., Su, S. N. P., Kotaki, Y., Leaw, C. P. (2012). Morphological observation of two species of Pseudonitzschia (Bacillariophyceae). Coastal Marine Science 35(1):52-57.

33. Teng S. T., Leaw C. P., Lim H. C. and Lim P. T. (2013). The genus Pseudo-nitzschia (Bacillariophyceae) in Malaysia, including new records and a key to species inferred from morphology-based phylogeny. Botanica Marina 56: 375-398.

34. Maria A.F. and Rose A.G. (2002). Identification Harmful Marine. Dinoflagellates. Smithsonian Institution Contributions from the United States National Herbarium 42:1-144.

35. Tan T.H., Lim P.T., Mohd. Razali R. and Leaw C.P. (2013). Harmful algal species in the Tebrau Strait: an SEM observation of the dinoflagellates assemblage. Annals of Microscopy 13: 4-13. waters. Sains Malaysiana 41(12): 1509 1515.

41. Glibert P.M., Landsberg J.H., Evans J.J., Al-Sarawi M.A., Faraj M., Al-Jarallah M.A., Haywood A., Ibrahem S., Klesius P., Powell C. and Shoemaker, C. (2002). A fish kill of massive proportion in Kuwait Bay, Arabian Gulf, 2001: the roles of bacterial disease, harmful algae, and eutrophication. Harmful Algae 1:215-231.

42. Jothy A.A. (1984). Status of shellfish toxicity and related problems in Malaysia. In: Toxic red tides and shellfish toxicity in Southeast Asia. (eds. White A.W., Anraku D.M. and Hooi K.). p. 33.

43. Fukuyo Y., Takano H., Chihara M. and Matsuoka K. (1990). Red tide organism in Japan-An illustrated taxonomic guide. Uchida Rokakuho. 